Удк 615.454.2:615.11 + 615.072

DOI https://doi.org/10.11603/2312-0967.2019.3.10443

\title{
ВИМОГИ ДО ЯКОСТІ СУПОЗИТОРІЇВ ЯК ЛІКАРСЬКОї ФОРМИ ВІДПОВІДНО ДО СВІТОВИХ ФАРМАКОПЕЙ
}

\author{
С. Л. Алейник, Ж. М. Полова \\ Національний медичний університет імені О. О. Богомольця, Київ \\ aleinyk_svitlana@ukr.net,zpolova@ukr.net
}

\section{ІНФОРМАЦІЯ}

Надійшла до редакції / Received: 28.08.2019

Після доопрацювання / Revised: 05.09.2019

Прийнято до друку / Accepted: 13.09.2019

\section{Ключові слова:}

супозиторії;

песарії;

контроль якості;

фрармакопеї.

\begin{abstract}
АНОТАЦІЯ
Мета роботи. Порівняльний аналіз даних світових фрармакопей щодо показників та їх норм, а також методик і методів, що визначають якість супозиторіїв як лікарської форми (ЛФ).

Матеріали і методи. Використано методи інформаційного пошуку, аналізу літературних джерел, порівняння, узагальнення.

Результати й обговорення. Визначення супозиторіїв як ЛФ у Державній Фармакопеї України, Державних Фармакопеях Республік Білорусь та Казахстан, Європейській та Британській фрармакопеях наведено у загальних фрармакопейних статтях (ЗФС) «Лікарські засоби для ректального застосування» та «Лікарські засоби для вагінального застосування» (як песарії). Фармакопеї США, Японії та Російської Федерації містять характеристику супозиторіїв у ЗФС на ЛФ. У ході аналізу встановлено, що для супозиторіїв та песаріїв визначаються такі основні показники якості: опис, ідентисрікація, однорідність маси, розпадання, розчинення, температура плавлення (для ліпофрільних основ), вміст домішок, кількісне визначення, мікробіологічна чистота.

Висновки. Проведений аналіз вказує на деякі відмінності даних світових срармакопей щодо контролю якості супозиторіїв та песаріїв. Це свідчить про необхідність гармонізації вимог фрармакопей для уніфікації методик та методів аналізу супозиторіїв та песаріїв як широко застосовуваних ЛФ.
\end{abstract}

Вступ. Біофрармацевтичними дослідженнями доведено, що терапевтична ефективність активного фармацевтичного інгредієнту (АФІ) при мінімальному виявленні побічних ефектів досягається лише при застосуванні оптимальної ЛФ при раціональному шляху введення [1].

На сьогодні існує значна кількість ЛФ, що застосовуються у таких важливих галузях медицини, як акушерство та гінекологія, проктологія, урологія, педіатрія $[2,3]$.

Супозиторії є традиційною ЛФ, що найчастіше застосовуються для місцевої або резорбтивної дії АФ। [3].
Саме для супозиторіїв характерні такі переваги:

$\checkmark$ відсутність побічної дії на шлунково-кишковий тракт;

$\checkmark$ швидке настання терапевтичного ефекту, пролонговане тривале вивільнення лікарського засобу (ЛЗ) порівняно з ін'єкційним способом введення, при цьому без порушення шкірних покривів;

$\checkmark$ забезпечення максимальної взаємодії між слизовою оболонкою та АФІ, без виявлення подразливої дії;

$\checkmark$ практична відсутність алергічних реакцій;

$\checkmark$ точність дозування;

$\checkmark$ відсутність специфічного смаку та запаху, характерних для деяких субстанцій;

ISSN 2312-0967. Pharmaceutical review. 2019. № 3 


\section{Reviews}

$\checkmark$ можливість застосування хворими при нудоті та блюванні;

$\checkmark$ можливість застосовування при невідкладних станах, оскільки велика частина АФІ швидко всмоктується у товстому кишечнику і безпосередньо потрапляє у системний кровотік через середні та нижні гемороїдальні вени, а також лімфатичні шляхи $[4,5]$.

Також варто зазначити, що ЛЗ у фрормі супозиторіїв широко використовують у педіатричній та геріатричній практиці, коли утрудненим $є$ пероральне та парентеральне введення лікарських препаратів (ЛП) $[4,6]$.

Серед негативних характеристик супозиторіїв можна виділити їхню термолабільність, адже більшість супозиторіїв потребують спеціальних умов зберігання та транспортування, можливість передчасного виведення препарату з місця введення (підтікання, десекація), неприємні гігієнічні аспекти їх застосування, а також негативний комлаєнс частини пацієнтів, адже багато хворих упереджено ставлять до даної ЛФ, що зумовлено певними культурними традиціями.

Отже, супозиторії мають багато переваг та мінімум недоліків порівняно з іншими ЛФ [6, 7].

3 фрізико-хімічної точки зору супозиторії - це дисперсні системи, що складаються з основи (дисперсійного середовища) і лікарських речовин (дисперсної фрази). Такі системи є складними багатокомпонентними гетерогенними системами, оскільки містять одну або більше лікарських речовин, диспергованих або розчинених у простій або складній основі, яка може розчинятися або диспергуватися у воді [8].

Перспективними удосконаленими формами супозиторіїв є ліофілізовані супозиторії, пресовані (таблетовані) супозиторії, пористі, порожнисті та багатошарові супозиторії, супозиторії на «шипучій» основі, мукоадгезивні магнітні, забарвлені супозиторії та супозиторії з плівковим покриттям. У виробництві даних ЛФ, окрім класичних методів, використовуються спеціальні технологічні прийоми (виморожування, вакуумування тощо) [7].

ЛП у формі супозиторіїв, як і будь-який л3, проходить всі етапи життєвого циклу. Відомо, що стандартизація є невід'ємною складовою, що гарантує якість та безпечність застосування Л3. Однією із тенденцій підвищення якості, есрективності та безпечності ЛЗ є гармонізація вимог до них [9].

Фармакопея - це офріційний нормативний документ, що визначає властивості, дію, використання, дозування, стандарти дії й чистоти АФІ, ЛЗ, ЛФ та розробляється під контролем професійного, державного, уповноваженого органу [10].

Фармакопеї США, Японії та Великобританії завжди були авторитетними у всьому світі. У 1964 р. була створена Європейська Фармакопея, що стандартизує вимоги до якості АФІ, загальні вимоги до ЛП, контролю якості тощо [10].

Фармакопея як збірник офріційних документів (стандартів та положень), що забезпечує належну якість Л3, відіграє значну роль у регулюванні обігу ЛП на світових національних фрармацевтичних ринках [11]. Гармонізація вимог фрармакопеї до ЛЗ $є$ неминучим процесом в інтегрованих умовах їх застосування та одним із шляхів розвитку фармакопейних стандартів [9].

Таким чином, метою даної роботи був порівняльний аналіз даних світових фрармакопей щодо показників та їхніх норм, а також методик і методів, що визначають якість супозиторіїв як ЛФ.

Матеріали і методи. Об'єкти дослідження: ЗФС на ЛФ у Державній Фармакопеї України (ДФУ) 2 видання, Європейській фрармакопеї 8 вид. (Ph. Eur.), Британській фрармакопеї (ВР), фрармакопеї Сполучених Штатів Америки 30 NF25 (USP), срармакопеї Японії (JP), Державній фрармакопеї Російської Федерації (ГФРФ), Державних фрармакопеях Республік Білорусь (ГФРБ) та Казахстан (ГФРК). Використано методи інорормаційного пошуку, аналізу літературних джерел, порівняння, узагальнення.

Результати й обговорення. У ході аналізу було встановлено, що визначення супозиторіїв як ЛФ у ГФРФ наведено у ЗФС на дану ЛФ, у JP - у загальній монографії на ЛП, у USP - у ЗФС на дозовані ЛФ. ДФУ, ГФРБ та ГФРК, Ph. Eur., а також ВР містять визначення супозиторіїв у статтях «ЛЗ для ректального застосування» (Rectalia) та «Л3 для вагінального застосування» (як песарії) (Vaginalia) (табл. 1) [12 - 20].

Згідно з ЗФС «ЛЗ для ректального застосування», окрім ректальних супозиторіїв, до них належать: ректальні капсули, ректальні розчини, емульсії та суспензії, порошки і таблетки для приготування ректальних розчинів або супензій, м'які ЛЗ для ректального застосування, ректальні піни та ректальні тампони.

До лЗ для вагінального застосування згідно з ДФУ, Ph. Eur., ГФРБ, ГФРК, ВР належать: песарії, вагінальні таблетки, вагінальні капсули, вагінальні розчини, емульсії та суспензії, таблетки для приготування вагінальних розчинів і суспензій, м'які ЛЗ для вагінального застосування, вагінальні піни та вагінальні медичні тампони.

Аналіз фрармакопей свідчить, що основними показниками якості, які визначаються для супозиторіїв та песаріїв, є органолептичні властивості (опис), ідентифрікація, середня маса та однорідність маси, номінальна маса або об'єм, однорідність вмісту, однорідність дозованих одиниць, розпадання, температура плавлення та час повної десормації, розчинення, механічна міцність (стійкість до роздавлювання), вміст домішок, мікробіологічна чистота, кількісне визначення, також за необхідності контролюють кислотне і перекисне число та розмір частинок тощо. Проте не у всіх фрармакопеях наведені вимоги всіх вищезазначених показників стосовно контролю якості супозиторіїв та песаріїв (табл. 2).

ISSN 2312-0967. Фармацевтичний часопис. 2019. № 3 
Таблиця 1

Визначення поняття «супозиторії» згідно з даними світових фрармакопей

\begin{tabular}{|c|c|c|}
\hline Нормативний документ & Назва статті & Визначення \\
\hline $\begin{array}{l}\text { Ph. Eur. } \\
\text { ДФУ } \\
\text { ВР } \\
\text { ГФРБ } \\
\text { ГФРК }\end{array}$ & $\begin{array}{l}\text { ЛЗ для ректального } \\
\text { застосування }\end{array}$ & $\begin{array}{l}\text { Ректальні супозиторії - тверді, однодозові Л3. Форма, об'єм і } \\
\text { консистенція мають відповідати ректальному застосуванню. } \\
\text { Вони містять одну або більше діючих речовин, диспергованих } \\
\text { або розчинених у підхожій основі, яка може розчинятися або } \\
\text { диспергуватися у воді, або плавитися при температурі тіла. }\end{array}$ \\
\hline $\begin{array}{l}\text { Ph. Eur. } \\
\text { ДФУ } \\
\text { ВР } \\
\text { ГФРБ } \\
\text { ГФРК }\end{array}$ & $\begin{array}{l}\text { ЛЗ для вагінального } \\
\text { застосування }\end{array}$ & $\begin{array}{l}\text { Песарії - тверді, однодозові ЛЗ. Вони можуть бути різної форми, } \\
\text { звичайно яйцеподібної, за об'ємом і консистенцією мають } \\
\text { відповідати вагінальному застосуванню. Вони містять одну } \\
\text { або більше діючих речовин, диспергованих або розчинених у } \\
\text { підхожій основі, яка може розчинятися або диспергуватися у } \\
\text { воді, або плавитися при температурі тіла. }\end{array}$ \\
\hline USP & $\begin{array}{l}\text { Фармацевтичні } \\
\text { дозовані фрорми }\end{array}$ & $\begin{array}{l}\text { Супозиторії - це тверді тіла різної ваги та форми, призначені } \\
\text { для введення у ректальну, вагінальну або уретральну } \\
\text { порожнину тіла. Вони звичайно плавляться, розм'якшуються } \\
\text { або розчиняються при температурі тіла. }\end{array}$ \\
\hline $\mathrm{JP}$ & $\begin{array}{l}\text { Загальні вимоги до } \\
\text { лП }\end{array}$ & $\begin{array}{l}\text { Супозиторії - це тверді ЛП, призначені для введення } \\
\text { в пряму кишку або порожнину піхви. Вони плавляться } \\
\text { або розм'якшуються при температурі тіла або повільно } \\
\text { розчиняються в секреторних рідинах. }\end{array}$ \\
\hline ГФРФ & Супозиторії & $\begin{array}{l}\text { Супозиторії - тверда при кімнатній температурі дозована ЛФ, } \\
\text { що містить одну або більше діючих речовин, розчинених або } \\
\text { диспергованих у підхожій основі, призначена для введення в } \\
\text { порожнини тіла і розплавляється при температурі тіла. }\end{array}$ \\
\hline
\end{tabular}

Таблиця 2

Показники якості супозиторіїв та песаріїв відповідно до даних фрармакопей

\begin{tabular}{|c|c|c|c|c|c|c|c|c|c|}
\hline \multirow{2}{*}{ № $3 / \Pi$} & \multirow{2}{*}{ Показник якості } & \multicolumn{8}{|c|}{ Наявність } \\
\hline & & Ph. Eur. & ДФУ & $\mathrm{BP}$ & USP & $\mathrm{JP}$ & ГФРФ & ГФРБ & ГФРК \\
\hline 1 & Опис & + & + & + & + & + & + & + & + \\
\hline 2 & Ідентифрікація & + & + & + & + & + & + & + & + \\
\hline 3 & Середня маса & - & + & - & - & - & - & - & + \\
\hline 4 & Однорідність маси & + & + & + & + & + & + & + & + \\
\hline 5 & Однорідність вмісту & + & + & + & + & + & - & + & + \\
\hline 6 & $\begin{array}{l}\text { Однорідність дозованих } \\
\text { одиниць }\end{array}$ & + & + & + & + & + & + & + & - \\
\hline 7 & Розпадання & + & + & + & - & - & + & + & + \\
\hline 8 & Температура плавлення & + & + & + & + & - & + & - & + \\
\hline 9 & Час повної деформації & - & + & - & - & - & + & + & + \\
\hline 10 & Розчинення & + & + & + & + & + & + & + & + \\
\hline 11 & Стійкість до руйнування & - & + & - & + & - & - & - & + \\
\hline 12 & Розмір частинок & + & + & + & - & + & + & + & - \\
\hline 13 & Вміст домішок & + & + & + & + & + & + & + & + \\
\hline 14 & Кількісне визначення & + & + & + & + & + & + & + & + \\
\hline 15 & Мікробіологічна чистота & + & + & + & + & + & + & + & + \\
\hline
\end{tabular}

Такі показники, як опис, ідентифрікація, однорідність маси, розчинення, вміст домішок, кількісне визначення та мікробіологічна чистота описані у всіх досліджуваних фрармакопеях.
ДФУ та ГФРК містять національну частину. У ЗФС ДФУ «ЛЗ для ректального застосування» та «ЛЗ для вагінального застосування» вказані такі показники: середня маса, температура плавлення, кількісне визначення.

ISSN 2312-0967. Pharmaceutical review. 2019. № 3 
У ГФРК у вищезгаданих статтях такі показники: однорідність вмісту, середня маса, температура плавлення, час повної десрормації, час розчинення, кількісне визначення.
У таблиці 3 вказані номери методик та норми показників якості, що визначаються для супозиторіїв та песаріїв.

У ЗФС «Мікробіологічна чистота» ГФРФ існують обмеження для препаратів бактеріофрагів, пробіоти-

Таблиця 3

Норми показників якості, що визначаються для супозиторіїв та песаріїв

\begin{tabular}{|c|c|c|c|c|}
\hline № 3/п & Показник & Фармакопея & Методика & Норми \\
\hline 1 & 2 & 3 & 4 & 5 \\
\hline \multirow{7}{*}{1} & \multirow{7}{*}{$\begin{array}{c}\text { Однорідність } \\
\text { вмісту }\end{array}$} & Ph. Eur. & \multirow{5}{*}{ 2.9.6 тест В } & \multirow{7}{*}{$\begin{array}{l}\text { При вмісті діючої речовини менше } 2 \text { мг або } \\
\text { менше } 2 \% \text { Л3 витримує випробування, } \\
\text { якщо вміст не більш як в одній одиниці } \\
\text { виходить за межі } 85-115 \% \text { і в жоднй } \\
\text { одиниці не виходить за межі } 75-125 \% \\
\text { від середнього вмісту л3 }\end{array}$} \\
\hline & & ГФРК & & \\
\hline & & ДФУ & & \\
\hline & & $\mathrm{BP}$ & & \\
\hline & & ГФРБ & & \\
\hline & & USP & 905 & \\
\hline & & $\mathrm{JP}$ & 6.02 & \\
\hline \multirow{8}{*}{2} & \multirow{8}{*}{ Однорідність маси } & ГФРК & \multirow{5}{*}{2.9 .5} & \multirow{6}{*}{$+-5 \%$} \\
\hline & & ГФРБ & & \\
\hline & & Ph. Eur. & & \\
\hline & & $\mathrm{BP}$ & & \\
\hline & & ДФУ & & \\
\hline & & ГФРФ & ЗФС.1.4.2.0009.15 & \\
\hline & & USP & 905 & \multirow{2}{*}{+-5 \%, окрім двох +-7,5 \% } \\
\hline & & $\mathrm{JP}$ & 6.02 & \\
\hline \multirow{7}{*}{3} & \multirow{7}{*}{$\begin{array}{c}\text { Однорідність } \\
\text { дозованих одиниць }\end{array}$} & ДФУ & \multirow{4}{*}{2.9 .40} & \multirow{7}{*}{$\begin{array}{c}\text { Обчислюють за показниками } \\
\text { прийнятності }\end{array}$} \\
\hline & & ГФРБ & & \\
\hline & & Ph. Eur. & & \\
\hline & & $\mathrm{BP}$ & & \\
\hline & & JP & 6.02 & \\
\hline & & USP & 905 & \\
\hline & & ГФРФ & $\begin{array}{c}\text { ЗФС.1.4.2.0008.15 } \\
\text { спосіб } 1\end{array}$ & \\
\hline \multirow{2}{*}{4} & \multirow{2}{*}{ Середня маса } & ГФРК & \multirow{2}{*}{2.9 .5} & \multirow{2}{*}{$+-5 \%$} \\
\hline & & ДФУ & & \\
\hline \multirow{6}{*}{5} & \multirow{6}{*}{ Розчинення } & ГФРК & 2.9 .3 & $\begin{array}{c}\text { За } 45 \text { хв у розчин повинно перейти не } \\
\text { менше ніж } 75 \text { \% і не більше ніж } 115 \% \\
\text { діючої речовини від її вмісту }\end{array}$ \\
\hline & & $\begin{array}{l}\text { ГФРБ } \\
\text { Ph. Eur. } \\
\text { ВР } \\
\text { ДФУ }\end{array}$ & $2.9 .3,2.9 .42$ & \multirow{3}{*}{$\begin{array}{c}\text { За } 45 \text { хв у середовище розчинення } \\
\text { повинно перейти не менше ніж } 75 \text { \% } \\
\text { діючої речовини, супозиторії та песарії на } \\
\text { гідрофрільній основі повинні розчинитися } \\
\text { не більше ніж за } 60 \text { хв }\end{array}$} \\
\hline & & JP & 6.10 & \\
\hline & & USP & 711 & \\
\hline & & \multirow{2}{*}{ ГФРФ } & $\begin{array}{l}\text { ЗФС.1.4.2.0014.15 } \\
\text { (для супозиторіїв на } \\
\text { гідрофрільній основі) }\end{array}$ & $\begin{array}{c}\text { У середовище розчинення за } 45 \text { хв } \\
\text { повинно вивільнитись не менше ніж } 75 \text { \% } \\
\text { діючої речовини }\end{array}$ \\
\hline & & & $\begin{array}{l}\text { ЗФС .4.2.0015.15 } \\
\text { (для супозиторіїв на } \\
\text { ліпоорільній основі) }\end{array}$ & $\begin{array}{c}\text { Повинно перейти у розчин не менше ніж } \\
75 \text { \% діючої речовини за певний проміжок } \\
\text { часу }\end{array}$ \\
\hline
\end{tabular}

ISSN 2312-0967. Фармацевтичний часопис. 2019. № 3 
Продовження табл. 3

\begin{tabular}{|c|c|c|c|c|}
\hline 1 & 2 & 3 & 4 & 5 \\
\hline \multirow{6}{*}{6} & \multirow{6}{*}{ Розпадання* } & ГФРК & \multirow{5}{*}{2.9 .2} & \multirow{6}{*}{$\begin{array}{c}\text { Для гідрофробних основ - не більше ніж } \\
30 \text { хв, для гідрофрільних основ та песаріїв } \\
\text { - не більше ніж } 60 \text { хв }\end{array}$} \\
\hline & & ДФУ & & \\
\hline & & ГФРБ & & \\
\hline & & Ph. Eur. & & \\
\hline & & BP & & \\
\hline & & ГФРФ & ЗФС. 1.4.2.0012.15 & \\
\hline \multirow{8}{*}{7} & \multirow{8}{*}{$\begin{array}{c}\text { Температура } \\
\text { плавлення }\end{array}$} & ГФРК & \multirow{5}{*}{2.2 .15} & \multirow{8}{*}{$\begin{array}{c}\text { Лише для ліпофрільних основ } \\
\text { Не більше ніж } 37^{\circ} \mathrm{C}\end{array}$} \\
\hline & & ДФУ & & \\
\hline & & $\mathrm{BP}$ & & \\
\hline & & Ph. Eur. & & \\
\hline & & ГФРБ & & \\
\hline & & ГФРФ & $\begin{array}{c}\text { ЗФС.1.2.1.0011.15 } \\
\text { метод } 2\end{array}$ & \\
\hline & & USP & 741 & \\
\hline & & $\mathrm{JP}$ & 2.60 & \\
\hline \multirow{4}{*}{8} & \multirow{4}{*}{$\begin{array}{c}\text { Час повної } \\
\text { десормації } \\
\text { супозиторіїв на } \\
\text { ліпофрільній основі }\end{array}$} & ГФРБ & רת ח & \multirow{4}{*}{ Не більше ніж 15 хв } \\
\hline & & ДФУ & $2.9 . \angle 2$ & \\
\hline & & ГФРК & $\begin{array}{c}\text { Додаток } 1 \text { до статті } \\
2.9 .22\end{array}$ & \\
\hline & & ГФРФ & ЗФС.1.4.2.0010.15 & \\
\hline \multirow{3}{*}{9} & \multirow{3}{*}{$\begin{array}{l}\text { Стійкість до } \\
\text { руйнування }\end{array}$} & ГФРК & 2924 & \multirow{3}{*}{ Вказано в окремій статті } \\
\hline & & ДФУ & & \\
\hline & & USP & 780 & \\
\hline \multirow{6}{*}{10} & \multirow{6}{*}{ Розмір частинок } & ГФРФ & ЗФС.1.2.1.0009.15 & \multirow{6}{*}{ Не більше 10 мкм } \\
\hline & & BP & \multirow{4}{*}{ 2.9.37 } & \\
\hline & & Ph. Eur. & & \\
\hline & & ДФУ & & \\
\hline & & ГФРБ & & \\
\hline & & $\mathrm{JP}$ & 6.03 & \\
\hline 11 & Вміст води & USP & 921 & Вказано в окремій статті \\
\hline \multirow{6}{*}{12} & \multirow{6}{*}{$\begin{array}{c}\text { Мікробіологічна } \\
\text { чистота }\end{array}$} & ГФРК & \multirow{5}{*}{5.1 .4} & \multirow{5}{*}{ 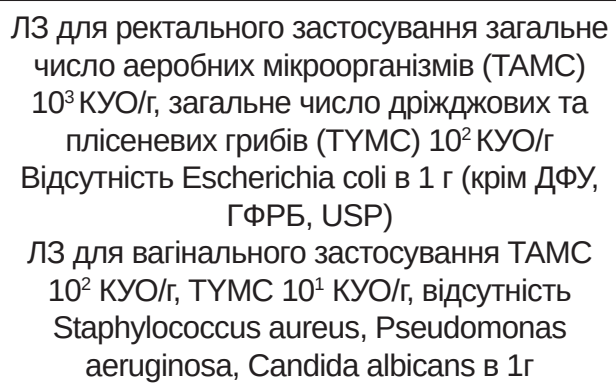 } \\
\hline & & ДФУ & & \\
\hline & & ГФРБ & & \\
\hline & & Ph. Eur. & & \\
\hline & & BP & & \\
\hline & & ГФРФ & ЗФС.1.2.4.0002.15 & $\begin{array}{c}\text { TAMC не більше ніж } 10^{3} \text { КУО в } 1 \text { г, } \\
\text { TYMC не більше ніж } 10^{2} \text { в } 1 \text { г, відсутність } \\
\text { Escherichia coli в } 1 \text { г, } \\
\text { Для інтравагінальних ЛФ - відсутність } \\
\text { Candida albicans в } 1 \text { г }\end{array}$ \\
\hline
\end{tabular}

Примітки: * - якщо проводять випробування за показником «Розчинення», випробування «Розпадання» не вимагається.

ISSN 2312-0967. Pharmaceutical review. 2019. № 3 
ків, імунобіологічних препаратів, в тому числі для ректального та інтравагінального введення, а у ГФРК ЗФС 5.1.4 носить не обов'язковий характер.

У кожній методиці є інорормація про необхідні реактиви та обладнання. Наприклад, для визначення розчинення використовують таке обладнання:

- прилад із кошиком складається із посудини зі скла або іншого інертного прозорого матеріалу, що може закриватися; мотора; ведучого вала; циліндричного кошика (перемішуючий елемент);

- прилад із лопаттю - використовують описану комплектацію приладу з кошиком, але як перемішуючий елемент встановлюють лопать, що складається із лопаті та вала;

- циліндри, що здійснюють зворотно-поступальні рухи - даний прилад складається 3 набору циліндричних плоскодонних скляних посудин; набору скляних циліндрів, що здійснюють зворотно-поступальні рухи; інертних штуцерів (виготовлених із нержавіючої сталі типу 316 або іншого підхожого матеріалу) і сит, виготовлених із підхожих несорбуючих і нереакційноздатних матеріалів, сконструйованих так, щоб закривати дно і верх циліндрів, що здійснюють зворотно-поступальні рухи; мотора і системи приводу, що приводить у вертикальний поворотно-поступальний рух циліндри всередині посудин, i, при бажанні, переміщує циліндри, що здійснюють зворотно-поступальні рухи, горизонтально в різних рядах посудин;

- проточна кювета - складається із резервуара та насоса для середовища розчинення; проточної кювети; водяної бані, що підтримує температуру середовища розчинення $(37+0.5)^{\circ} \mathrm{C}$.

У ГФРК, ГФРФ, JР описані лише перші три прилади.

Висновки. 1. Проведено аналіз даних Ph. Eur., ДФУ, ВР, ГФРБ, ГФРК, ГФРФ, USP та ЈР щодо визначення супозиторіїв як ЛФ та основних показників, що визначають якість супозиторіїв.

2. Визначено основні показники і критерії якості супозиторіїв (ректальних та вагінальних) та методики визначення.

3. Проведене дослідження вказує на деякі відмінності даних світових фрармакопей щодо контролю якості супозиторіїв та песаріїв. Це свідчить про необхідність гармонізації вимог фрармакопей для уніфікації методик та методів аналізу супозиторіїв та песаріїв як широко застосовуваних ЛФ.

Конфолікт інтересів: відсутній.

Conflicts of interest: authors have no conflict of interest to declare.

\title{
REQUIREMENTS FOR QUALITY OF SUPPOSITORIES AS A DOSAGE FORM IN ACCORDANCE WITH THE WORLD PHARMACOPOEIAS
}

\author{
S. L. Aleinyk, Zh. M. Polova \\ O. Bohomolets National Medical University, Kyiv \\ aleinyk_svitlana@ukr.net, zpolova@ukr.net
}

The aim of the work. Comparative analysis of the world pharmacopoeias data for definition the indicators and their norms and also methods that determine the quality of suppositories as dosage form.

Materials and Methods. Methods of information search, analysis of literary resources, comparison, generalization are used.

Results and Discussion. Definition of suppositories as dosage form in the State Pharmacopoeia of Ukraine, State Pharmacopoeias of the Republics of Belarus and Kazakhstan, European and British Pharmacopoeias are given in general pharmacopoeia articles "Drugs for rectal use" and "Drugs for vaginal use" (as pessaries). The US Pharmacopoeia, Japanese Pharmacopoeia, and the State Pharmacopoeia of the Russian Federation contain a description of suppositories in general pharmacopoeia articles on dosage forms. During the analysis established that for the suppositories and pessaries the basic quality indicators: appearance, identification, uniformity of mass, disintegration, dissolution, melting point (for lipophilic bases), content of impurities, quantitative determination, microbiological quality are determined.

Conclusions. The analysis shows some differences of the data of pharmacopoeias regarding the quality control of suppositories and pessaries. This indicates the need to harmonize the requirements of pharmacopoeias for unification of quality control methods of suppositories and pessaries as widely used dosage forms.

Key words: suppositories; pessaries; quality control; pharmacopoeias.

ISSN 2312-0967. Фармацевтичний часопис. 2019. № 3 


\title{
ТРЕБОВАНИЯ К КАЧЕСТВУ СУППОЗИТОРИЕВ КАК ЛЕКАРСТВЕННОЙ ФОРМЫ В СООТВЕТСТВИИ С МИРОВЫМИ ФАРМАКОПЕЯМИ
}

\author{
С. Л. Алейник, Ж. Н. Полова
}

Национальный медицинский университет имени А. А. Богомольца, Киев

aleinyk_svitlana@ukr.net, zpolova@ukr.net

Цель работы. Сравнительный анализ данных мировых фрармакопей относительно показателей и их норм, а также методик и методов, определяющих качество суппозиториев как лекарственной формы.

Материалы и методы. Использованы методы инорормационного поиска, анализа литературных источников, сравнение, обобщение.

Результаты и обсуждение. Определение суппозиториев как лекарственной фрормы в Государственной Фармакопее Украины, Государственных фрармакопеях Республик Беларусь и Казахстан, Европейской и Британской фрармакопеях изложено в общих фрармакопейных статьях «Лекарственные средства для ректального применения» и «Лекарственные средства для вагинального применения» (как пессарии). Фармакопеи США, Японии и Российской Федерации содержат характеристику суппозиториев в общих фрармакопейных статьях на лекарственные фрормы. В результате анализа было установлено, что для суппозиториев и пессариев определяются следующие основные показатели качества: описание, идентификация, однородность массы, распадаемость, растворение, температура плавления (для липосильных основ), содержание примесей, количественное определение, микробиологическая чистота.

Выводы. Проведенный анализ указывает на некоторые отличия данных мировых фрармакопей относительно контроля качества суппозиториев и пессариев. Это свидетельствует о необходимости гармонизации требований фрармакопей для унисрикации методик и методов анализа суппозиториев и пессариев как широко используемых лекарственных фрорм.

Ключевые слова: суппозитории; пессарии; контроль качества; фрармакопеи.

\section{Список літератури}

1. Половко Н. П. Оцінка біофрармацевтичних фракторів при розробці та виробництві нових лікарських засобів / Н. П. Половко, Л. І. Вишневська, О. С. Шпичак // Сучасні досягнення фрармацевтичної технології біотехнології: зб. наук. пр. - Х., 2017. - С. 155 - 160.

2. Орлова Т. В. Современные ректальные, вагинальные и уретральные лекарственные фрормы / Т. В. Орлова // Вестник ВГУ. - 2014. - № 1. - С. 126 - 133.

3. Проблемы создания и стандартизации суппозиториев на современном этапе / Т. А. Панкрушева, Л. Н. Ерофеева, Т. В. Орлова [ и др.] // Курский науч.практ. вестник «Человек и его здоровье». - 2016. № 2. - C. $108-112$.

4. Глущенко О. М. Порівняльна характеристика асортименту супозиторних лікарських засобів на ринках України та Російської Федерації / О. М. Глущенко, Р. С. Каневський // Ліки України. - 2015. - № 2 (23). C. $87-91$.

5. Justification of surface-active substances choice in composition of suppositories for treatment of benign diseases of prostate gland / V. S. Zaychenko, O. A. Ruban, Ju. S. Masliy, N. A. Gerbina // Укр. біофрармацевт. журнал. 2017. № 6 (53). С. 4-8.

6. Дзюба А. С. Современное состояние и перспективы развития рынка суппозиториев / А. С. Дзюба, Е. О. Трофримова // Фармация. - 2014. - № 3. C. $27-30$.

7. Суппозитории. Современный взгляд на лекарственную форму : монографр. / Т. А. Панкрушева, Л. Н. Ерофеева, Т. В. Орлова, О. О. Курилова. - Курск : КГМУ, 2017. -212 c
8. Грабов Л. М. Використання методів термоконтактного нагрівання та дискретно-імпульсного введення енергії в технології одержання супозиторіїв / Л. М. Грабов, Д. В. Посунько, О. Є. Степанова // Пром. теплотехника. - 2015. - Т. 38, №1. - С. 31 - 40.

9. Кондратьева И. А. Требования фрармакопей к ректальным суппозиториям / И. А. Кондратьева, И. Е. Смехова // Фармация. - 2012. - № 1. - С. 54-56.

10. Фармацевтична енциклопедія [Електронний ресурс]. URL : https://www.pharmencyclopedia.com.ua.

11. Титова А. В. Роль фрармакопеи в условиях глобализации экономики стран и пути ее развития / А. В. Титова, Н.П.Садчикова // Ведомости НЦЭСМП. - 2016. - № 2. - C. $42-49$.

12. Державна фрармакопея України: в 3 т. / Укр. наук. фармакоп. центр якості лікар. засобів. - 2-е вид. X., 2015. - T. 1. - 1128 c.

13. Государственная фрармакопея Республики Беларусь: в 2 т. / Центр экспертиз и испытаний в здравоохранении. - Молодечно : Тип. «Победа», 2012. - Т.1. Общие методы контроля лекарственных средств. $1220 \mathrm{c}$.

14. Государственная фрармакопея республики Казахстан. - 1-е изд. - Алматы : Издательский дом «Жибек жолы», 2015. - Т. 1. - 720 с.

15. Государственная фармакопея Российской Федерации: в 3 т. / МЗ РФ. - XIV изд.- Москва, 2018. - Т. 1. $-1815 \mathrm{c}$.

16. Государственная фармакопея Российской Федерации: в 3 т. / МЗ РФ. - XIV изд. - Москва, 2018. - Т. 2. -1449 c.

ISSN 2312-0967. Pharmaceutical review. 2019. № 3 
17. Japanese Pharmacopoeia. - 16th ed. - Токіо, 2011.$2326 \mathrm{p}$.

18. The British Pharmacopoeia. - 12th ed. - London: HMSO, 2015. - 6024 p.

19. European Pharmacopoeia. - 8th ed. - Strasbourg: Council of Europe, 2015. - 6111 p.

20. The United States Pharmacopoeia 37: The National Formulary 32. - New York, 2014. - 2569 p.

\section{References}

1. Polovko NP, Vyshnevska LI, Shpychak OS. [Evaluation of the biopharmaceutical factors at the development and production of new drugs]. Suchasni dosiahnennia farmatsevtychnoi tekhnolohii i biotekhnolohii: zb. nauk. pr. - Kh., 2017; 155-160. Ukrainian.

2. Orlova TV. [Modern rectal, vaginal and urethral medicinal forms]. Vestnik VGU. 2014;1: 126-33. Russian.

3. Pankrusheva TA, Erofeeva LN, Orlova TV, Kurilova OO, Chekmareva MS. [Problems of formulation and standardization of suppositories in the modern period]. Kurskij nauch.-prakt. vestnik "Chelovek i ego zdorovye". 2016;2: 108-12. Russian.

4. Hlushchenko OM, Kanevskyi RS. [Comparative characteristics assortment of suppositorial medicines in the markets of Ukraine and Russia]. Liky Ukrainy. 2015;2(23): 87-91. Ukrainian.

5. Zaychenko VS, Ruban OA, Masliy JuS, Gerbina NA. [Justification of surface-active substances choice in composition of suppositories for treatment of benign diseases of prostate gland]. Ukr biofarmatsevt zhurnal. 2017;6(53): 4-8. Ukrainian.

6. Dzyuba AS, Trofimova EO. [The suppository market: state-of-the-art and development prospects]. Farmatsiya. 2014;3: 27-30. Russian.

7. Pankrusheva TA, Erofeeva LN, Orlova TV, Kurilova OO. Suppositories. Modern view at the dosage form: monograph [Суппозитории. Современный взгляд на лекарственную форму: монограф.] Kursk: KGMU; 2017. Russian.

8. Hrabov LM, Posunko DV, Stepanova OYe. [Application methods of thermocontact heating and discrete pulse input energy in technologies of obtaining suppositories]. Prom. teplotehnika, 2015; 38(1): 31-40. Ukrainian.

9. Kondratyeva IA, Smehova IE. [Pharmacopoeial requirements for rectal suppositories]. Farmatsiya. 2012;1: 546. Russian.

10. Pharmaceutical encyclopedia. [Фармацевтична енциклопедія] [Electronic resource, Ukrainian.]. Available from: https://www.pharmencyclopedia.com.ua. Ukrainian.

11. Tytova AV, Sadchynkova NP. [The role of pharmacopoeia in the context of globalization of world economics and its development prospects]. Vedomosty NCESMP. 2016;2: 42-9. Russian.

12. State Pharmacopoeia of Ukraine: in 3 vol. [Державна Фармакопея України: в 3 т.] 2nd ed. Kharkiv State Enterprise "Ukrainian Research Center expert pharmacopoeia drug quality", 2015. Ukrainian.

13. State Pharmacopoeia of Belarus Republic: in 2 vol. [Государственная фрармакопея Республики Беларусь: в 2 т.] Vol.1. General methods of drug control. Center for Expertise and Testing in Health Care, 2012. Russian.

14. State Pharmacopoeia Kazakhstan Republic. Vol 1. 1 ed. [Государственная фрармакопея республики Казахстан], Almaty, 2015. Russian.

15. State Pharmacopoeia of Russian Federation: in 3 vol. [Государственная фрармакопея Российской Федерации: в 3 т.] Vol.1. Moscow, 2018. Russian.

16. State Pharmacopoeia of Russian Federation: in 3 vol. [Государственная фрармакопея Российской Федерации: в 3 т.] Vol.2. Moscow, 2018. Russian.

17. Japanese Pharmacopoeia. 16th ed. Tokio, 2011.

18. The British Pharmacopoeia. 12th ed. London: HMSO, 2015.

19. European Pharmacopoeia. 8th ed. Strasbourg: Council of Europe, 2015.

20. The United States Pharmacopoeia 37: The National Formulary 32. New York, 2014

\section{Відомості про авторів:}

Алейник С. Л. - асист. кафедри аптечної та промислової технології ліків, Національний медичний університет імені О. О. Богомольця, Київ, Україна. E-mail: aleinyk_svitlana@ukr.net, ORCID 0000-0003-2901-9189

Полова Ж. М. - д. фрармац. н., доцент, завідувач кафедри аптечної та промислової технології ліків, Національний медичний університет імені О. О. Богомольця, Київ, Україна. E-mail:zpolova@ukr.net, ORCID 0000-0002-1874-2841

\section{Information about the authors:}

Aleinyk S. L. - assistant of the Pharmaceutical and Industrial Technology of Medicines Department, O. O. Bohomolets National Medical University, Kyiv, Ukraine. E-mail: aleinyk svitlana@ukr.net, ORCID 0000-0003-2901-9189

Polova Zh. M. - DS (Pharmacy), Associate Professor, Head of the Pharmaceutical and Industrial Technology of Medicines Department, O. O. Bohomolets National Medical University, Kyiv, Ukraine. E-mail:zpolova@ukr.net, ORCID 0000-00021874-2841 